\title{
KINERJA SOSIAL DAN KINERJA KEUANGAN PERUSAHAAN \\ (LITERATUR REVIEW)
}

\author{
Anggita Langgeng Wijaya \\ Pendidikan Akuntansi IKIP PGRI MADIUN \\ Gonggeng14@gmail.com
}

\begin{abstract}
This paper discusses the relation of corporate social performance with financial performance. This paper is a literature review of research types. With reference to the stakeholder theory, firm with good social performance is expected to be able to accommodate the interests of the stakeholders, so as to have a good relationship from the external environment. With a good relationship with its stakeholders expect corporate managers are able to manage the company more efficiently, have the convenience of the source of funding, have low business risk and have a good appreciation of the market value. From the study of literature to some previous studies it can be concluded that corporate social performance will have a positive impact on the financial performance of the company.
\end{abstract}

Keyword: corporate social performance, financial performance, stakeholder theory

\begin{abstract}
Abstrak
Paper ini membahas tentang corporate sosial performance kaitannya dengan kinerja keuangan perusahaan. Paper ini merupakan jenis penelitian literature review. Dengan mengacu pada stakeholder teori, perusahaan dengan kinerja sosial yang baik diharapkan mampu untuk mengakomodasi kepentingan pada stakeholder, sehingga dapat memiliki hubungan yang baik dari lingkungan eskternal. Dengan hubungan yang baik dengan para stakeholdernya diharapkan manajer perusahaan mampu mengelola perusahaan dengan lebih efisien, memiliki kemudahan pada sumber pendanaan, memiliki risiko bisnis rendah dan memiliki apresiasi nilai pasar yang baik. Dari telaah literature terhadap beberapa penelitian sebelumnya dapat disimpulkan bahwa kinerja sosial perusahaan akan berdampak positif terhadap kinerja keuangan perusahaan.
\end{abstract}

Kata kunci : Kinerja sosial perusahaan, kinerja keuangan, stakeholder teori.

\section{PENDAHULUAN}

Orlitzky et al (2003) mengungkapkan bahwa dalam satu dekade terakhir, perusahaan banyak mendapatkan tekanan dari stakeholder mereka untuk menjadi "good corporate citizenship" dalam bisnis. Tekanan tersebut melahirkan konsep yang disebut dengan corporate sosial performance. Corporate sosial performance merupakan konfigurasi strategi bisnis atas prinsip tanggungjawab sosial, proses dari respon sosial, kebijakan, program dan outcome lain yang dapat diobservasi berkaitan dengan hubungan sosial perusahaan (Wood (1991) dalam Orlitzky et al (2003)). Sebuah perusahaan didirikan dengan tujuan untuk mensejahterakan pemilik perusahaan. 
Sebagai sebuah organisasi bisnis tentunya profit manjadi tujuan utama sebuah perusahan. Epstein (2007) menyatakan bahwa mengimplentasikan strategi secara bersama dalam upaya mencapai keberlanjutan yang luar biasa dalam bidang sosial dan kinerja keuangan merupakan isu yang menjadi tantangan baik bagi akademisi maupun praktisi untuk menelitinya. Epstein (2007) menyatakan bahwa kinerja keuangan perusahaan bersifat jangka pendek, terukur dan dapat dengan mudah untuk dinilai keberhasilannya. Hal ini berbeda dengan kinerja sosial perusahaan yang bersifat jangka panjang, abstrak, tidak mudah untuk diukur dan tidak mudah untuk di amati. Melalui paper ini penulis akan melalui review terhadap beberapa penelitian terhadulu untuk mencoba memberikan pemahaman keterkaitan antara kinerja sosial dengan kinerja keuangan perusahaan.

\section{TEORI STAKEHOLDER}

Robert (1992) menyatakan bahwa teori stakeholder merupakan teori yang dinilai tepat untuk menjelaskan dan menjadi dasar penelitian terkait dengan tanggungjawab sosial perusahaan. Freeman (1984) dalam Robert (1992) menyatakan bahwa stakeholder adalah indivudu atau kelompok yang dapat dipengaruhi atau mempengaruhi pencapaian dari tujuan perusahaan. Stakeholder perusahaan meliputi pemegang saham, kreditur, konsumen, suplier, masyarakat umum, dan pemerintah. Manurut teori stakeholder, tujuan perusahaan adalah menjaga kemampuan untuk menyeimbangkan potensi terjadinya konflik antara semua stakeholder perusahaan. Secara sederhana, teori ini menjelaskan bahwa kegiatan sosial yang dilakukan oleh perusahaan merupakan tindakan yang dilakukan untuk menjaga kepentingan seluruh stakeholder perusahaan.

Epstein (2007) melakukan penelitian yang bersifat filed study pada perusahaanperusahaan di Amerika yag dinilai sukses menjaga secara bersama-sama antara kinerja sosial dan kinerja keuangan perusahaan. Perusahaan tersebut adalah Nike, Procter \& Gamble, the Home Depot, dan Nissan North America. Penelitian ini menyebutkan bahwa manajer selalu berhati-hati tentang apa yang akan menjadi reaksi stakeholder dalam setiap keputusan yang diambil. Organisasi harus menerapkan sistem yang mampu membantu manajer untuk dapat belajar tentang pengelolaan aspek sosial dan aspek finansial. Perusahaan menemukan bahwa perusahaan harus membuat strategi sosial dan strategi keuangan secara terintegrasi.

Orlitzky dan Benjamin (2001) menyatakan dari perspektif stakeholder teori, kinerja sosial perusahaan diharapkan mampu menurunkan resiko keuangan perusahaan. Dalam perkembangan bisnis terkini, adanya tuntutan litigasi dari lingkungan bisnis merupakan risiko yang tinggi bagi perusahaan, jika hal tersebut terkait dengan pembuatan strategi maka ada potensi perusahaan untuk mengulang strategi dari awal. Pada sisi yang lain, perusahaan dengan kinerja sosial perusahaan yang baik memiliki hubungan yang baik dengan stakeholder internal maupun eksternal perusahaan. Kinerja sosial perusahaan meliputi perhatian yang mendalam tentang lingkungan yang menjadi perhatian berbagai stakeholder. Secara umum pada pendekatan stakeholder, risiko keuangan perusahaan diantisipasi dengan peningkatan kinerja sosial perusahaan.

\section{CORPORATE SOSIAL PERFORMANCE}

Menurut Cowen et al. (1967) dalam Robert (1992), beberapa penelitian sebelumnya telah mencoba menjelaskan corporate social responsibility sebagai sebuah aktivitas atau kebijakan yang terkait dengan isu-isu kemasyarakatan. Kegiatan sosial perusahaan meliputi beberapa aspek seperti: aspek lingkungan, affirmative action 
program, kesamaan dan hak-hak pekerja, pemberdayaan komunitas, keamanan produk, kebijakan Negara-negara tertinggal, kebijakan energi dan pengungkapan tanggungjawab sosial.

Epstein (2007) menjelaskan bahwa menyeimbangkan antara aspek sosial dan performance keuangan secara bersama merupakan tantangan baik bagi perusahaan profit maupun nonprofit pada semua level manajerial. Implementasi sering gagal karena banyak perusahaan tidak memasukannya dalam aspek budaya organisasi dan aspek kepemimpinan. Dengan mengembangkan model Wood (1991), Orlitzky dan Benjamin (2001) menggunakan empat pengukuran corporate sosial performance yaitu: CSP disclosure, CSP reputation rating, sosial audit, CSP proses, dan observable outcome, dan CSR yang meliputi manajerial CSP principal dan value.

Orlitzky dan Benjamin (2001) menyatakan bahwa investasi kinerja sosial perusahaan bersifat jangka panjang. Kinerja sosial perusahaan diharapkan meningkatkan hubungan baik dengan para stakeholder, sehingga monitoring cost dapat berkurang. Terdapat hubungan yang erat antara reputasi kinerja sosial perusahaan dengan persepsi positif dari investor dan diantara kinerja sosial perusahaan dan risiko pasar. Dari sisi konsumen, para konsumen sudah sangat cerdas dengan lebih memilih membeli produk dari perusahaan dengan yang bertanggungjawab secara sosial dari pada perusahaan yang tidak bertanggungjawab. CSP harus lebih visible untuk dapat dipahami oleh stakeholder perusahaan dan menyakinkan para stakeholder bahwa kinerja sosial perusahaan telah mampu memuaskan stakeholder (Orlitzky dan Benjamin, 2001).

\section{CORPORATE SOSIAL PERFORMANCE DAN KINERJA KEUANGAN}

Orlitzky et al. (2003) menyatakan bahwa jika mengacu pada stakeholder teori maka keterkaitan antara kinerja sosial perusahaan dan kinerja keuangan adalah positif. Kepuasan berbagai pihak yang merupakan stakeholder perusahaan akan memberikan dampak yang positif terhadap kinerja keuangan organisasi. Kemampuan manajer untuk berdialog dan memperoleh kepercayaan dari stakeholder akan kemampuan perusahaan untuk menjaga hubungan dengan pihak eksternal. Menurut (Freeman dan Evan, (1990) dalam Orlitzky et al. (2003) menjelaskan bahwa kinerja sosial perusahaan tidak hanya meningkatkan dan kerjasama bilateral dengan stakeholder, namun juga secara simultan melakukan kordinasi dan memperioritaskan kepentingan seluruh stakeholder perusahaan.

Orlitzky dan Benjamin (2001) menyatakan bahwa kinerja sosial perusahaan akan berdampak positif terhadap peningkatan kinerja keuangan perusahaan seperti return on asset dan apresiasi harga saham perusahaan. Orlitzky dan Benjamin (2001) juga menyatakan bahwa kinerja sosial perusahaan akan meningkatkan efisiensi dan pengelolan perusahaan, meningkatkan kepercayaan para stakeholder yang dapat berdampak pada penurunan risiko perusahaan. Risiko perusahaan mengukur fruktuasi keuntungan perusahaan disetiap waktu yang dapat berdampak pada fruktuasi harga saham perusahaaan dan secara internal berdampak pada risiko akuntansi. Hasil penelitian Orlitzky dan Benjamin (2001) menunjukkan bahwa kinerja sosial perusahaan menurunkan risiko bisnis dan risiko pasar perusahaan.

Bayoud et al. (2012) melakukan penelitian tentang hubungan antara pengungkapan corporate social responsibility pada kinerja organisasi dengan sampel 40 perusahaan di negara Lybia tahun 2007 sampai dengan 2009. Penelitian ini menguji indeks pengungkapkan tanggungjawab sosial perusahaan dengan kinerja keuangan perusahaan, komitmen pegawai dan reputasi perusahaan. Hasil penelitian ini 
menunjukkan bahwa semakin tinggi indeks pengungkapan tanggungjawab sosial akan semakin tinggi kinerja keuangan dan semakin tinggi reputasi perusahaan. Namun hasil penelitian ini tidak menemukan keterkaitan antara pengungkapan tanggungjawab sosial dengan komitmen karyawan.

Abid (2013) melakukan penelitian tentang proses berkelanjutan dari bisnis dikaitkan kinerja keuangan perusahaan. Aktivitas lingkungan dan aktivitas sosial perusahaan merupakan upaya perusahaan untuk memiliki proses bisnis yang berkelanjutan. Tekanan untuk melakukan kegiatan sosial semakin meningkat terkait dengan kepentingan berbagai stakeholder perusahaan. Hasil penelitian ini menunjukkan bahwa indeks kegiatan sosial perusahaan akan berdampak terhadap efisiensi bisnis, risiko perusahaan dan operasional manajemen. Hasil penelitian ini juga menunjukkan bahwa indeks kinerja sosial berbeda untuk jenis industri manufaktur dan jasa. Kegiatan sosial terinterasi dalam upaya mewujudkan proses bisnis yang berkelanjutan dan kinerja perusahaan.

Perusahaan dengan CSP yang tinggi akan memperoleh kepercayaan yang lebih tinggi dari para stakeholder perusahaan. Yang pertama, perusahaan dengan hubungan stakeholder yang stabil akan mampu mengatasi kesulitan-kesulitan dalam investasi pada ekuitas baru. Yang kedua, lender dan investor memiliki perhatian khusus terhadap aspek sosial, perusahaan dengan CSP rendah akan memiliki akses yang terbatas di pasar modal, serta menurunkan risiko keuangan (McGuire, Sundgren dan Schneeweis (1988) dalam Orlitzky dan Benjamin (2001)). Perusahaan dengan kinerja sosial yang tinggi dihadapkan memiliki profitabilitas keuangan yang lebih baik jika dibandingkan dengan perusahaan dengan kinerja sosial yang rendah.

\section{KESIMPULAN}

Paper ini merupakan kajian literatur yang mencoba melakukan review tentang keterkaitan antara kinerja sosial perusahaan dan kinerja keuangan perusahaan. Dengan mengacu pada stakeholder teori, perusahaan dengan kinerja sosial yang baik diharapkan mampu memprioritaskan kepentingan pemegang saham, menurunkan risiko bisnis dan meningkatkan kinerja keuangan dan kinerja pasar perusahaan. Berdasarkan hasil literature review dapat disimpulkan bahwa kinerja sosial perusahaan berpengaruh positif terhadap kinerja keuangan perusahaan. 


\section{DAFTAR PUSTAKA}

Abid, Kanzah. 2013. Integration Of Corporate Sustainability With Business Processes and Its Impact On Corporate Performance. Interdisciplinary Journal of Contemporary Research in Business. Vol. 4, No.9, Pp. 863-885.

Bayoud, Nagib Salem; Marie Kavanagh; dan Geoff Slaughter. 2012. An Empirical Study Of The Relationship Between Corporate Social Responsibility Disclosure and Organizational Performance: Evidence From Libya. Global Conference on Business and Finance Proceedings. Volume 7. Number 2

Epstein. 2007. The Challenge of Simultaneously Improving Sosial and Financial Performance New Research Results Studies in Managerial and Financial Accounting Vol 20: Performance and Management Control: Innovative Concept and Practices, pp 3-18.

Orlitzky, M. dan Benjamin, J. D. 2001. 'Corporate social performance and firm risk: A meta-analytic review', Business \& Society 40(4), pp.369-396

Orlitzky, M., Schmidt, F. L. \& Rynes, S. L. 2003. 'Corporate sosial and financial performance: A meta-analysis', Organization Studies, 24(3), pp. 403-441

Robert, Robin W. 1992. Determinants Of Corporate Sosial Responsibility Disclosure: An Application Of Stakeholder Theory. Accounting Organizations and Society, Vol. 17, No 6, pp 595-612. 